VILNIUS GEDIMINAS TECHNICAL UNIVERSITY

Aušra KALANTAITE

\title{
AN IMPROVEMENT OF THE TECHNOLOGIES OF THE LIDAR MEASUREMENTS AND APPLICATIONS FOR THE MODELLING OF THE EARTH PHYSICAL SURFACE
}

SUMMARY OF DOCTORAL DISSERTATION

TECHNOLOGICAL SCIENCES, MEASUREMENT ENGINEERING (10T)

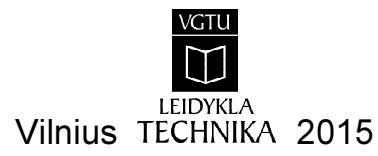


Dissertation was prepared at Vilnius Gediminas Technical University in 20092015

Scientific Supervisor

Prof. Dr Eimuntas Kazimieras PARŠELIŪNAS (Vilnius Gediminas

Technical University, Technological Sciences, Measurement Engineering 10T).

The dissertation is being defended at the Council of Scientific Field of Measurement Engineering at Vilnius Gediminas Technical University: Chairman

Prof. Dr Habil. Vladas VEKTERIS (Vilnius Gediminas Technical

University, Technological Sciences, Measurement Engineering - 10T). Members:

Assoc. Prof. Dr Domantas BRUČAS (Vilnius Gediminas Technical University, Technological Sciences, Measurement Engineering - 10T),

Prof. Dr Mindaugas JUREVIČIUS (Vilnius Gediminas Technical

University, Technological Sciences, Measurement Engineering - 10T),

Prof. Dr Habil. Kazys KAZLAUSKAS (Vilnius University, Physical

Sciences, Informatics - 09P),

Dr Habil. Saulius ŠLIAUPA (Vilnius University, Physical Sciences,

Geology - 05P).

Opponents:

Prof. Dr Vladislovas Česlovas AKSAMITAUSKAS (Vilnius Gediminas

Technical University, Technological Sciences, Measurement

Engineering - 10T),

Dr Jonas SATKŪNAS (Lithuanian Geological Survey under the Ministry of Enviroment, Physical Sciences, Geology - 05P).

The dissertation will be defended at the public meeting of the Council of Scientific Field of Measurement Engineering in the Senate Hall of Vilnius Gediminas Technical University at 10 a. m. on 15 December 2015.

Address: Sauletekio al. 11, LT-10223 Vilnius, Lithuania.

Tel.: +370 5274 4952, +370 5274 4956; fax +370 5270 0112;

e-mail: doktor@vgtu.lt

The summary of the doctoral dissertation was distributed on 13 November 2015. A copy of the doctoral dissertation is available for review at VGTU repository http//dspace.vgtu.lt/ and at the Library of Vilnius Gediminas Technical University (Sauletekio al. 14, LT-10223 Vilnius, Lithuania). 
VILNIAUS GEDIMINO TECHNIKOS UNIVERSITETAS

Aušra KALANTAITE

LIDAR MATAVIMŲ IR TAIKYMŲ

TECHNOLOGIJŲ

TOBULINIMAS FIZINIAM ŽEMĖS

PAVIRŠIUI MODELIUOTI

DAKTARO DISERTACIJOS SANTRAUKA

TECHNOLOGIJOS MOKSLAI, MATAVIMŲ INŽINERIJA (10T)

Vilnius TECHNIKA 2015 
Disertacija rengta 2009-2015 metais Vilniaus Gedimino technikos universitete.

Mokslinis vadovas:

prof. dr. Eimuntas Kazimieras PARŠELIŪNAS (Vilniaus Gedimino technikos universitetas, technologijos mokslai, matavimų inžinerija - 10T).

Disertacija ginama Vilniaus Gedimino technikos universiteto Matavimų inžinerijos mokslo krypties disertacijos gynimo taryboje:

Pirmininkas:

prof. habil. dr. Vladas VEKTERIS (Vilniaus Gedimino technikos Nariai: universitetas, technologijos mokslai, matavimų inžinerija - 10T).

doc. dr. Domantas BRUČAS (Vilniaus Gedimino technikos universitetas, technologijos mokslai, matavimų inžinerija - 10T), prof. dr. Mindaugas JUREVIČIUS (Vilniaus Gedimino technikos universitetas, technologijos mokslai, matavimų inžinerija - 10T), prof. habil. dr. Kazys KAZLAUSKAS (Vilniaus universitetas, fiziniai mokslai, informatika - 09P),

habil. dr. Saulius ŠLIAUPA (Vilniaus universitetas, geologija - 05P). Oponentai:

prof. dr. Vladislovas Česlovas AKSAMITAUSKAS (Vilniaus

Gedimino technikos universitetas, matavimų inžinerija - 10T), dr. Jonas SATKŪNAS (Lietuvos geologijos tarnyba prie Aplinkos ministerijos, geologija - 05P).

Disertacija bus ginama viešame Matavimų inžinerijos mokslo krypties disertacijos gynimo tarybos posėdyje $2015 \mathrm{~m}$. gruodžio $15 \mathrm{~d}$. 10 val. Vilniaus Gedimino technikos universiteto senato posėdžių salèje.

Adresas: Saulètekio al. 11, LT-10223 Vilnius, Lietuva.

Tel.: (8 5) 274 4952, (8 5) 274 4956; faksas (8 5) 270 0112;

el. paštas doktor@vgtu.lt

Disertacijos santrauka išsiuntinèta $2015 \mathrm{~m}$. lapkričio $13 \mathrm{~d}$.

Disertaciją galima peržiūrèti VGTU talpykloje http://dspace.vgtu.lt/ ir

Vilniaus Gedimino technikos universiteto bibliotekoje (Sauletekio al. 14, LT-10223 Vilnius, Lietuva).

VGTU leidyklos „Technika“ 2348-M mokslo literatūros knyga.

(C) Aušra Kalantaitè, 2015 


\section{Introduction}

Problem statement. Over the past years, Light Detection and Ranging (LIDAR) laser scanning systems have been rapidly evolving to acquire ever-best accuracy and reliability. It has become one of the fastest ways for earth surface modelling. Extremely large amounts of scanned data render manual filtering of scanned results and quality control unfeasible. Being indispensable, automatic filtering methods have become subject to close studies.

The thesis deals with challenges emerging for the physical earth surface modelling. The earth surface modelling needs to eliminate redundancy geodetic height measurements collected through automated laser scanning; automatic area height measuring must identify surface break-lines; height interpolation accuracy evaluations must be made against the earth surface model. To address the first problem, it is necessary to retain the characteristics of the surface, leaving its typical surface features, but stripping away the arbitrary ones. To address the second problem, it is important to identify features representing the steep changes in the surface (edges of slopes, cliffs, etc.). To address the third problem, a comprehensive analysis of mathematical-statistical laser and control measurements must be completed.

To sample characteristic feature points, it is appropriate to apply the analysis of distance and height differences between the tested and the neighbouring points. These methods enable us to judge whether the point can be considered as ordinary within the accepted tolerance. For the sampling of characteristic points, an algorithm needs to be generated to evaluate the outcomes of the neighbourhood analysis of each point. The thesis deals with the algorithms for filtering laser scanning measurements (points) based on fitting of local planes.

Relevance of research. Various public administration processes rely on mapping details of specific objects existing in the respective locality. The collection of mapping data involves object positioning measurements, digital surveying plans, maps, geographic information systems, etc. Measuring geodetic heights by traditional methods, i.e. total stations, only minimum amount of information is collected. Low density of height points on the terrain of prominent relief encumbers the development of a high-quality earth surface model. Scanning from aircraft or ground scanning methods are widely used for largescale terrain surface digital modelling. The main advantage of the LIDAR application is LIDAR ability to collect massif information on surface elevations in short time.

Primary LIDAR-collected data include not only earth surface elevations, but also measurements of plants, cars, buildings and other objects (Digital Terrain Model, DTM). Laser scanning creates a dense three-dimensional point 
(3D) array, which includes all the measurements of the objects in the focus of the scanner. Many applications, for example - tracing horizontals, road designing, volume calculations, bank erosion monitoring - require the Digital Surface Model (DSM), which makes an accurate identification of relief break-lines. Raw LIDAR data are of limited use in the processes of construction designing and actual construction.

The volume of the array of points must be sufficient for the development of a high quality surface model, without being excessive at the same time. In some cases, LIDAR surface scanning data happen to be excessive, which means that points cover densely both the planes and rugged terrain areas. Creating terrain relief models redundant points become node points of the surface network, thus creating network elements arbitrary in the representation of the surface. Redundant elements of the surface model slows down the operation of the automated designing systems. Also, the excessive density of LIDAR points, without additional filtering, makes it unfeasible, at least for now, to generate a mapping printout.

Focus of research. Modelling of physical earth surface according to the primary LIDAR measurements results.

Aim of research. To improve the LIDAR measurements processing methodology for the earth surface modelling.

Research objectives. To achieve the aims of the research, the following objectives have been raised:

1. To review the existing scientific literature on mathematical processing methods of LIDAR measurements.

2. To examine the impact of filtering algorithms applied in commercial software on the quality of the earth surface model.

3. To propose the LIDAR redundant measurements elimination algorithm.

4. To evaluate the accuracy of the terrain models developed.

Research methodology. The study on filtering of LIDAR excessive measurements was based on the local planes fitting technique, while the study of earth's surface modeling applied the statistical analysis and interpolation techniques.

Scientific novelty of research. The research has produced the following novel results in the science of measuring engineering:

1. Suggestion of algorithm for eliminating the redundant LIDAR measurements results, decreasing the volume of data, but preserving the quality of earth surface models. 
2. Identification of parameter range for the algorithm of the elimination of geodetic heights points, while the terrain model quality remains unchanged.

3. Evaluation of the accuracy of the terrain models developed by the local interpolation technique, applying the mathematical statistical techniques.

4. Evaluation of the accuracy of some LIDAR measurements, applying the mathematical statistical techniques.

Practical value. The proposed LIDAR measurements processing algorithm is focused on non-commercial functions libraries. LIDAR data filtered with the developed software and earth surface models are applicable in the processes of designing and in the actual construction. LIDAR measurements have been used for the most accurate (at least for now) relief model of the Lithuanian territory.

\section{Defended statements}

1. The application of the proposed LIDAR points filtering algorithm can reduce the points array without any negative impact on the quality of the constructed earth surface model.

2. The application of relief break-lines detection algorithm enables the identification of surface edges at target range precision appropriate for drawing maps at a scale 1:2000 and smaller scales.

3. In the methodology used for the establishment of the values of indicators of earth surface models it is necessary to take into account the accuracy parameters of these indicators.

\section{List of abbreviations used}

The thesis consists of the introduction, three chapters and a general conclusion. The work covers 108 pages, with 43 formula, 62 figures and 17 tables. The reference list includes 113 source of literature.

\section{Analysis of research on LIDAR measurement filtering}

The first chapter reviews the research of other authors, introducing the existing LIDAR data filtering techniques and developed algorithms.

The analysis of the literature has shown a large number of authors working to achieve the optimum filtering algorithm. In the conclusions of the publications, the authors admit failure to develop LIDAR filtering algorithm for an automatic sampling of characteristic earth surface points in different localities. 
It has transpired through the analysis of the literature that the earth surface modelling currently poses a relevant scientific challenge, which has led to the formulation of research direction.

\section{Physical earth surface modelling}

The second chapter describes the filtering of the excessive LIDAR array of points applied in surface modelling, by eliminating redundant points and leaving only the characteristic surface points, thus preserving the authenticity of the surface. Characteristic points are those points that are detected in height variation spots. They include edges of slopes, boundaries of gullies and similar relief. To retain all surface-characterizing forms, it is necessary to sample redundant points, i.e. those on the same plane under the applicable tolerance.

The application of local planes in tested point and setting tolerance distance from the fitted plane corresponds to the sampling of neighbouring points through an oblique (adaptive slide) restricting cylinder. Distances are measured along the local tangent plane near the tested point (Fig. 1). This neighbourhood is calculated in two steps: first, restricting vertical cylinder dimensions are used to determine the points-contenders to the neighbourhood; the contenders are fitted with local plane, and the points that are below the maximum distance to the fitted plane are considered as the neighbours.

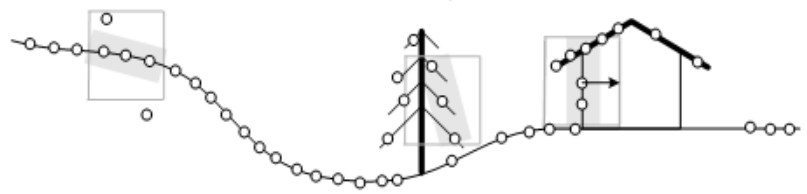

Fig. 1. Distance-to-the plane measuring variants

Algorithm parameters are obtained by evaluating the characteristics of LIDAR data. To determine the radius of the cylinder, it is necessary to evaluate the density of points and the size of LIDAR beam footprint of the earth. Assuming that the cylinder radius is smaller than the distance between the points, results in zero-rate neighbourhoods. To calculate the local surface, more than three points are required, but scanning noise interference must be taken into account.

When fitting the plane to vertical or close to vertical surfaces, vertical distance from the plane to the point becomes more important than the height difference in the vertical from point to plane. Since points representing vertical planes scanned from aircraft were relatively few, the aim was to achieve that the 
developed algorithm, following the change in the 3D point sampling feature, would be applicable for the identification of plane edges in the terrestrial scanning spatial datasets.

The method of least squares fits the plane to a certain volume of data, and assumes that inaccuracies of plane fitting for the set of points are distributed in the direction of heights. This method best suits for orthogonal data, which can be displayed in the orthographic projection.

The algorithm relies on eigenvector detection technique, thus minimizing the perpendicular from the point to the plane rather than the vertical distance from the point to the plane. The technique fits the plane described by the equation $a x+b y+c z+d=0$, by the restriction $a^{2}+b^{2}+c^{2}=1$ and obtains an optimal evaluation of the plane and its fitting in the case when the margins of error for the set of points for plane fitting are distributed at the direction perpendicular to the fitted plane.

Mathematical software options (e. g. Matlab) realize the calculation search algorithms of eigenvalues and eigenvectors. In order for the plane fitting and edge detection algorithm to operate in spatial data management software environment, scientific software was developed to calculate the eigenvalues and vectors in Python programming language. Additional feature libraries ArcPy Library, NumPy, Math were used. For the realisation of the algorithm, the Jacobi method was applied.

The algorithm developed under Jacobi method determines the direction of the vector of perpendicular to the plane, where the nominal plane equation is $x$ $\cos a+y \cos b+z \cos c-d=0$, and $-d$ is the plane distance from the origin point. The distances from each point to the fitted plane are used for the calculation of the mean squared error. The algorithm checks whether obtained eigenvalues are not the same in the accuracy limits of calculation. This case indicates that the points are located symmetrically to one another and the plane cannot be fitted.

The experiment involves 90047 height measuring points in 2.3 hectare area, simulating the reconstruction of the road, forming a new road base at $0.8 \mathrm{~m}$ depth from the existing road surface (Fig. 2.2). Altimetry is completed with carequipped scanner. Evaluation criteria for experiment results are as follows: reduction of points through filtering with the proposed algorithm; the difference in volumes of newly designed road earthworks, calculated with the terrain model developed according to all of the height points and the filtered ones.

Two experiments were completed applying neighbourhood distances $\mathrm{d}=0.5 \mathrm{~m}$ and $\mathrm{d}=1.5 \mathrm{~m}$. At value $\mathrm{d}=0.5 \mathrm{~m}$ the result is $0 \mathrm{~m}<\mathrm{RMS}<0.18 \mathrm{~m}$. At value $\mathrm{d}=1.5 \mathrm{~m}$ the result is $0 \mathrm{~m}<\mathrm{RMS}<0.36 \mathrm{~m}$. The results show, that the margin of error of fitting the plane, when the neighbourhood is $0.5 \mathrm{~m}$ points, is optimistic 
and prevents from a reliable sampling of height points on the edges of the relief and the adjacent points.

Increasing the neighbourhood coverage up to $1.5 \mathrm{~m}$ distance, the results received enable reliable classification of height points against the mean-square values of plane fitting. $0.05 \mathrm{~m}$ RMS value reliably identifies the terrain break-lines.

Following the identification of the reliable value of neighbourhood coverage and a meaningful value of plane fitting error, the common set of height points eliminates (filters) points adjacent to locally-fitted planes (RMS $<0.05 \mathrm{~m}$ ). Following the application of the described filter, only 12982 from 90047 height points remained in the set.

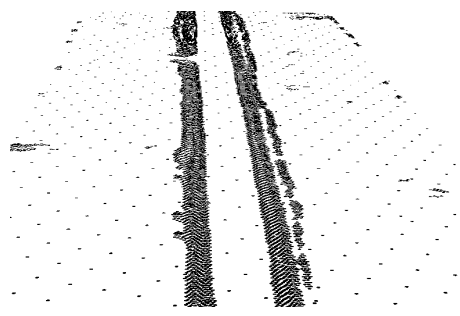

Fig. 2. Sampled points after application of locally-fitted planes technique $(\mathrm{RMS}<0.05 \mathrm{~m})$

The experiment aims to determine whether the sampled points are sufficient for the development of high quality terrain model intended for road designing with automated tools. Since direct comparison of the two surface models does not provide the possibility of judging on the importance of the difference in volume (land) for the value of construction works, a typical static road reconstruction project model was developed, and it was assumed that it would cover earthworks area of $7 \mathrm{~m}$ distance from the existing road axis, additional lanes in both directions would be planned, and the earthmoving depth to build the new road would be $0.8 \mathrm{~m}$.

Differences in terrain surface models are illustrated in Fig. 2.3. It shows that the horizontals drawn at $0.5 \mathrm{~m}$ are very close in both the first and second models. This indicates that the filtration did not compromise the surface representation quality.

The bottom of Fig. 2.3 shows several simulated road subgrade design cross sections; filling shows earthworks volumes (in case of application of filtered set of points). 
During the experiment of earth subgrades in the control transverse profiles, differences in height between the primary and the filtered terrain models were established. Surface height differences were calculated against the control point 21 . The biggest difference value accounts for $0.09 \mathrm{~m}$. Average height tolerance of control points is $0.02 \mathrm{~m}$.

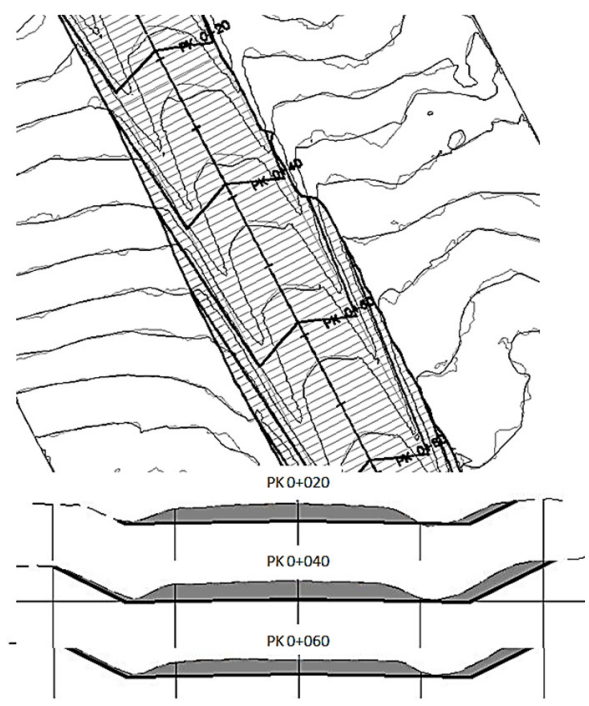

Fig. 3. Fragment of experimental project of road construction

Another study aims to identify the optimal parameters of TIN compaction filtering method while smoothing earth's surface and thinning the array of excessive LIDAR scanned points. The experiment compares earth surfaces created by using array of points filtered in different ways to earth surface created by using unfiltered LIDAR scanned points (the reference surface). The main evaluation criterion is the difference in earth volume.

The research baseline is the margin of error of earthwork volume calculated by filtered points. The accuracy of the estimated earthworks volume depends on the distribution, density and accuracy of height points. It must be taken into consideration that in practice the calculation of volumes involves levelling of areas through territorial breakdown in a regular grid.

The area selected for the experiment in Vilnius: the White Bridge vicinity (Fig. 4). The territory in question has a continuous surface. There is a low and gentle hillside, road with asphalt coating, street curbs, and pavements. The 
average road curb height stands at 0.10 to $0.22 \mathrm{~m}$. There are 515000 LIDAR scanned earth points with heights between $86.34-103.43 \mathrm{~m}$. The average point density is $2-3$ points per sq. $\mathrm{m}$.
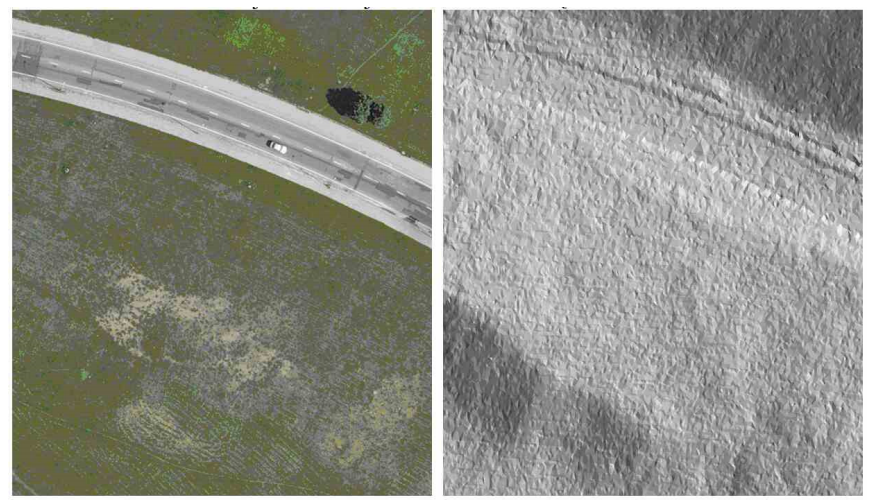

Fig. 4. Experimental territory in Vilnius city $(150 \times 150 \mathrm{~m})$

The reduction of points is intended to reduce the number of surface points. Parameters are chosen: maximum distance (Distance) and maximum change of the height of the point $(D z)$ and the parameter for the point on the thinned surface (Keep).

The feature divides surface points into groups according to the selected maximum horizontal distance. Based on the established maximum elevation (maximum vertical distance) each group retains one point. Which point retains in the group depends on the selected Keep parameter. Keep parameter values: leaving the Highest point for each group, the Lowest point, Central Point which is in the middle of the group, or derive the group point average (Create average).

Experimentally it has been confirmed that earth surface volumes are influenced by the selected parameter Keep, as well as variants Highest Point, and Lowest Point. Points thinning parameters were applied: Distance $-2.0 \mathrm{~m} \mathrm{Dz}-$ $0.10 \mathrm{~m}$. In all cases, the number of points after thinning feature accounted for $11.7 \%$ of the primary number of points. The most accurate original surface remains after thinning by leaving Central Point in the middle or deriving group point average (Create average).

Experimentally it is confirmed that earth surface volumes are influenced by values of the selected parameters Distance and $D z$. Points thinning parameters were applied: horizontal distance of $0.5 ; 1.0 ; 5.0 \mathrm{~m}$ and vertical $-0.05 ; 0.10 \mathrm{~m}$ ). It is obvious that the minimum thinning parameters bring in errors to the created 
surface. However, smoothing the established acceptable $250 \mathrm{cu}$. $\mathrm{m}$ error in this case meet 5.0/0.05 m parameter values. The application of these parameters results in the almost five-fold reduction of point array volume.

\section{Study of physical earth surface model applications}

The third chapter covers differences between the development and application of vector and raster physical earth surface models. The primary LIDAR data format is very simple and it can be viewed in a simple text editor, but such reporting format greatly increases the volume of data, also complicating data processing and immediate assessment of data volume and character (density and arrangement of measuring points, etc.). Each text file occupies several hundred megabytes, but in some cases they may exceed of 1 GB. The primary LIDAR data are used for surface modelling to be applied for practical purposes.

For planning and designing height information is required at a specific fixed location (e.g. asphalt cover height in the middle of the intersection) or large-scale coverage (e.g. to calculate earthwork volume). Height measuring spots are sampled through random scanning of the area, as well as through direct methods. However, there is always a need to create an earth model for the customers to have height characteristics at any spot of the surface. The selection of the type of the physical earth surface is relevant for practical application of the data, therefore extensively discussed.

Physical earth surface model applications call for a different structure of the physical earth surface model. The designing of structures (especially engineering networks and roads or rail) requires a high accuracy earth surface model. In these cases, vector-based representation model - the Triangulated Irregular Network (TIN) is used. The TIN model uses all the points of the primary set. The redundant points in the primary set are eliminated before the development of the model; the points are filtered, by eliminating the arbitrary ones in terms of the accuracy of the developed TIN model.

In the initial stages of designing of a structure, while selecting a concept or creating predesign solutions, it is sufficient to use a simpler structure of the physical earth surface model. In such cases, the raster-based representation model (GRID) is used. The development of a raster-based surface model involves the distribution of the entire array of the primary measurements into a regular network of cells, thus creating an array of regularly spaced interpolated points.

The LIDAR analysis of the accuracy of the data of the Lithuanian cities has produced the following estimates of the standard LIDAR accuracy: scanning of $800 \mathrm{~m}$ height produced estimates of the accuracy of the heights of points of laser pulses \pm 0.05 to $0.07 \mathrm{~m}$, and the biggest planimetric error is $0.25 \mathrm{~m}$. The visual review of the tested LIDAR data-based terrain model reveals the obvious fact 
that it gives a much more realistic and detailed representation of Lithuania's surface than the terrain models developed by interpolating height points obtained through ordinary surveying, or digitalized from large-scale maps, etc. The detailed results are achieved from a very high density of primary LIDAR data, measurement accuracy, and relatively even distribution of measuring points.

The experiment of the earth surface modelling uses an array of height LIDAR measurements from the air with the point density of 4 per sq. m; planned error not to exceed $0.30 \mathrm{~m}$; the height error not to exceed $0.50 \mathrm{~m}$. In the first stage, the primary height measurement points array was interpolated through the nearest neighbour method to $1 \times 1 \mathrm{~m}$ grid cells (SRM1). The next stage involved two variants of height values at the control point: through the bilinear interpolation, and the spatial overlay. The study concludes by comparing the interpolated normal heights values and normal heights measured regardless of primary measurements at the same spot (Fig. 5).

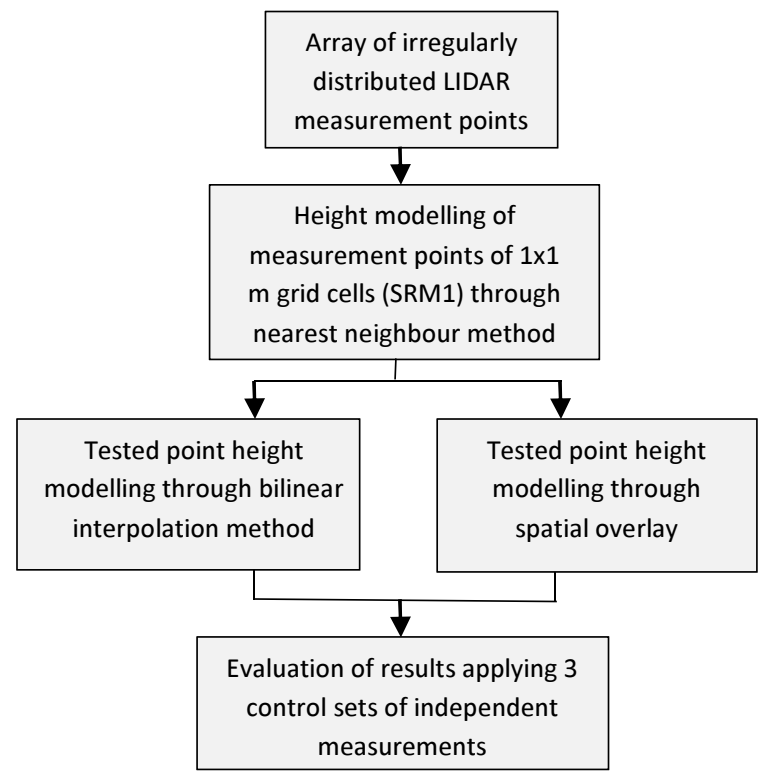

Fig. 5. Chart of research methodology for the earth surface model research

Thereby a situation is modelled for the SRM1 user to have specific point heights through the choice of the following: the use of the height value of the SRM1 cell or interpolation between four neighbouring cell values. Other local interpolation methods have not been subject to research, as SRM1 is created 
against the points, which are less than $1 \mathrm{~m}$ apart from each other, and the inclusion of further neighbouring SRM1 cells would lead away from the relevant solution.

To confirm the suitability of the selected interpolation methods, we need to compare the interpolated normal heights with the reference normal heights at the same spot. Three point arrays have been used: the normal heights of Lithuanian National GPS network points; the normal heights of the first and the second class vertical network points; the normal heights of orthographic maps and contourmarking.

The normal heights of GPS point have been found under SRM1 by two methods: by attributing the normal height of a raster cell (nearest neighbour interpolation method applied for the creation of the primary SRM1) or by interpolating between adjacent raster cells (use bilinear interpolation method). Normal height differences achieved are illustrated in Fig. 6.

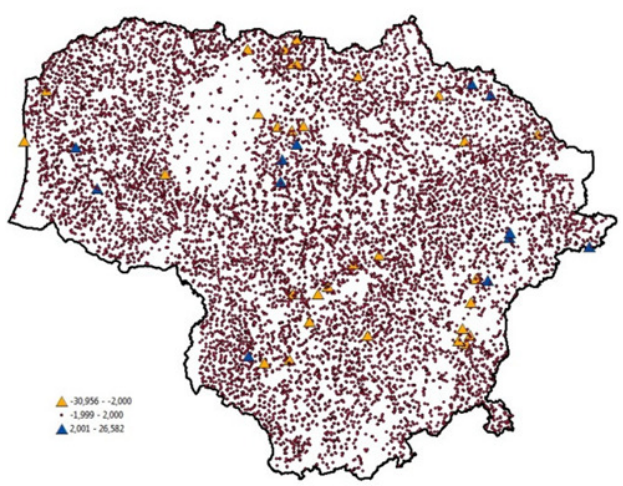

Fig. 6. The normal height differences at the Lithuanian National GPS network points, achieved against catalogue normal heights and against normal heights achieved with

SRM1, assigning normal heights of SRM1 cells to the points

The determination of the normal height values of the three tested point sets through the interpolation of the closest neighbours and through the application of the bilinear interpolation, the following standard deviations have been achieved, respectively: $0.344 \mathrm{~m}$ and $0.341 \mathrm{~m} ; 0.496 \mathrm{~m}$ and $0.502 \mathrm{~m}$; $0.256 \mathrm{~m}$ and $0.255 \mathrm{~m}$. The results achieved show that after the breakdown of the primary set of LIDAR measurement points into grid cells, further interpolation based on the values of these cells does not increase the accuracy of the determined values, which leads to the conclusion that higher accuracy of 
unknown points requires interpolation of the primary set of LIDAR measurement points.

Physical earth surface is composed of different natural and artificial surfaces. Various coatings with different intensity reflect laser pulse. The research aims to determine which earth surfaces are worse in reflecting (diffusing) laser pulse and thus reducing the accuracy of the measurements heights; and to establish LIDAR data application fields.

The experiment involved laser scanning results of Vilnius city in 2007 and height points captured on 1: 2000-scale topographic plan (Fig. 7). To assess the impact on the accuracy of model heights by the interpolation of primary laser scanning data, two experiments were conducted: 1) heights of laser scanning points were compared to the heights of the adjacent points on the survey plan; 2) heights of the points on the survey plan were compared with the earth surface model developed through the interpolation of laser scanning data. Each case analysed four surfaces of different reflection intensity: cement, asphalt, forest and meadows.

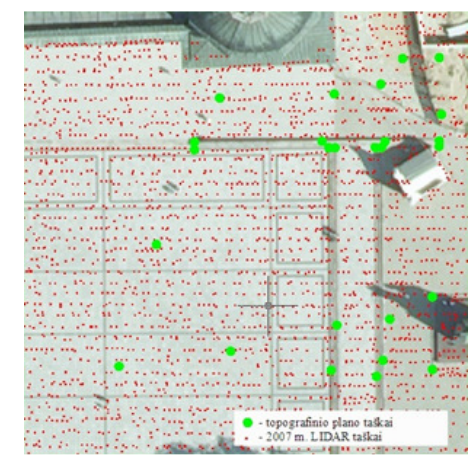

Fig. 7. Fragment of distribution of LIDAR (in red) and topographic plan points (in green) on cement cover

The analysis of height points by type of cover shows that the accuracy of laser-scanned heights depends on the type of the cover of the earth surface. The greatest accuracy is achieved with laser beam being reflected by artificial surfaces (errors up to $0.15 \mathrm{~m}$ ), while the lowest accuracy is in case of the surface being covered with dense vegetation, bushes (error up to $3.78 \mathrm{~m}$ ).

The research results confirm that accuracy of scanned height data of wooded areas is insufficient for planning of engineering infrastructure (standard deviation is $1.10 \mathrm{~m}$ ). LIDAR scanning of the woods is recommended for predesign stage (e.g. selecting routes for rail or road). 
The research results confirm that the accuracy of interpolated LIDAR data in open areas compared to the primary LIDAR measurements is reduced, i.e. height error extremes in open areas demonstrate double-fold increase. Height accuracy, impacted by the reflection of a specific type of cover has less influence than surface break-lines, which, through the interpolation, reduce the accuracy of model heights.

Experiment data were obtained by scanning with scanner Optech Altman 3100 from an airplane An-2. This type of lasers generate spatial "point cloud" of scanned surface reflections under the principle of deviating mirror principle. Geo-positioning is effected through an inertial navigation system Trimble 750 GPS-Applanix POS/AV IMU (Inertial Measurement Unit). Altman 3100 operates with infrared laser beams, close to visible range of the optical spectrum (1.047 micrometres). Flight details: $800 \mathrm{~m}$ height; $800 \mathrm{~m}$ distance between flight axles; $30 \%$ side scan line overlay; $3-4$ points per sq. m laser point density; $0.5 \mathrm{~m}$ average distance between the points. Experimental laser-scanned height points were classified by the supplier according to the morphological characteristics, into buildings, vegetation, bridges and surface groups of points (Fig. 8).

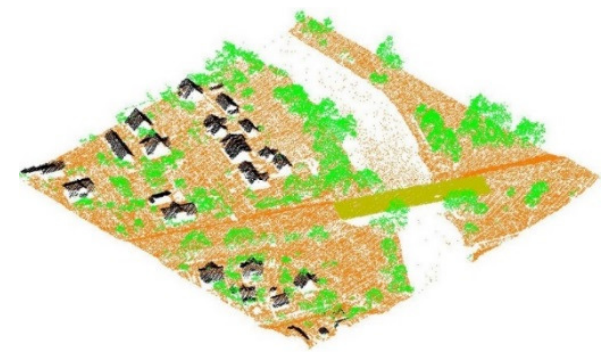

Fig. 8. Laser scanning points of a segment of Marijampolè city

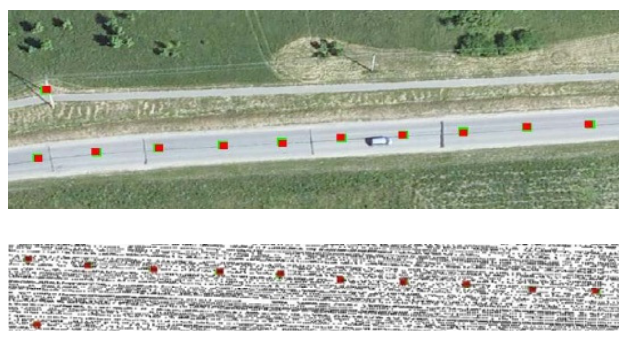

Fig. 9. LIDAR height points checked at Marijampole city: $a$ - orthophotographic image; $b$ - laser points cloud 
The experiment involved finding the nearest neighbours for geodetically coordinated points in LIDAR data, pointing out the difference in point height (Fig. 9). Neighbourhood search range $-0.3-0.5 \mathrm{~m}$. The resulting altitudinal deviation is illustrated in Table 4.

Table 4. Distribution of height deviations

\begin{tabular}{|l|c|c|c|c|c|c|c|}
\hline \multirow{3}{*}{ Cities } & \multicolumn{8}{|c|}{ Number of deviations in intervals, $\mathrm{m}$} \\
\cline { 2 - 8 } & \multirow{2}{*}{ zero } & \multicolumn{2}{|c|}{$0.01-10$} & \multicolumn{2}{c|}{$0.11-0.20$} & \multicolumn{2}{c|}{$0.21-0.30$} \\
\cline { 2 - 8 } & & + & - & + & - & + & - \\
\hline Kaunas & 6 & 155 & 38 & 102 & 3 & 2 & - \\
Panevěžys & 25 & 59 & 126 & 6 & 14 & - & 4 \\
Marijampole & - & 18 & - & - & - & - & - \\
Utena & 2 & 106 & 15 & 14 & 1 & - & - \\
\hline
\end{tabular}

The data of accuracy of laser pulse positioning of the points show that the height root-mean-square error (RMS) is $0.05-0.07 \mathrm{~m}$, to compare with 0.09 $0.11 \mathrm{~m}$ under the unfavourable reflection surface (Kaunas). The standard deviations of the heights are from 0.03 to $0.07 \mathrm{~m}$. The largest absolute displacement of planimetric LIDAR points is $0.25 \mathrm{~m}$, i.e. $1 / 3200$ of flying altitude.

\section{General conclusions}

1. The methodology of the mathematical processing of LIDAR measurements was improved by the proposed algorithm for redundant LIDAR points eliminating applying planes. This algorithm can reduce the points array without any negative impact on the quality of the constructed earth surface model.

2. The experiments confirm that following the breakdown into the grid cells of the primary LIDAR set of measurement points, the repeated interpolation on the basis of the cell values does not increase the height accuracy of the tested points, which leads to the conclusion that the interpolation of the primary set of LIDAR measurement points is required to achieve a higher accuracy of the value of unknown points requires.

3. The research results confirm the reduced accuracy of interpolated LIDAR data in open areas compared to the primary LIDAR measurements, i.e. height error extremes in open areas demonstrate double-fold increase. Height accuracy, impacted by the reflection of a specific type of cover has less influence than surface break-lines, which, through the interpolation, reduce the 
accuracy of model heights. The research results confirm that the accuracy of scanned height data of wooded areas is insufficient for planning of engineering infrastructure (standard deviation is $1.10 \mathrm{~m}$ ). LIDAR scanning of the woods is recommended for predesigning (e.g. selecting routes for rail or road).

4. The experimental research confirms that the accuracy of LIDAR data-based (flight height is not bigger than $800 \mathrm{~m}$, density of points is not lower than 4 points per sq. m) earth surface model satisfies the requirements of surveying data for urban area development planning at scales 1:500-1:2000: standard deviations of points heights are till $0.10 \mathrm{~m}$, while standard deviations of points plane positions are up to $0.25 \mathrm{~m}$. But the accuracy of such model is not suitable for construction designing at the scale of 1:500 due to the fact that in large-scale designing the measured heights errors tend to exceed $8 \mathrm{~cm}$.

\section{List of published works on the topic of the dissertation in the reviewed scientific periodical publications}

Stankevičius, Žilvinas; Beconytè, Giedrè; Kalantaitè, Aušra. 2010. Automation of update of digital national geo-reference databases. Technological and economic development of economy: Baltic journal on sustainbility, 16(2): 254-265. ISI Web of Science.

Stankevičius, Ž.; Kalantaite, A. 2009. LIDAR žemès paviršiaus taškų masyvo supaprastinimo algoritmų parametrų parinkimas, Geodesy and Cartography, 35(2): 44-49.

Žalnierukas. A,; Ruzgienė B,; Kalantaitė A,; Valaitienė R,; 2009. Miestų skenavimo LIDAR metodu tikslumo analizè, Geodesy and Cartography, 35(2): 55-60.

Kalantaitè, A.; Putrimas, R.; Šlikas, D. 2010. Erdvinių skenavimo duomenų taikymas vietovės trimačiams modeliams generuoti, Geodesy and Cartography, 36(4): 151-155.

Aleksejenko, Ivars; Sakne, Janis; Kalinka, Maris; Reiniks, Martins; Kalantaite, Aušra; Krikštaponis, Boleslovas; Paršeliūnas, Eimuntas; Petroškevičius, Petras; Viskontas, Povilas. 2012. The united geodetic vertical network of Latvia and Lithuania, Geodesy and Cartography, 38(1): 9-19.

Kalantaitè, A.; Paršeliūnas, E., K.; Romanovas, D.; Šlikas, D. 2012. Generating the open space 3d model based on LiDAR data, Geodesy and Cartography, 38(4) 152-156.

Šlikas, Dominykas; Kalantaite, Aušra. 2013. Vietovès trimačių modelių generavimas taikant erdvinius skenavimo duomenis, Aviation technologies, 1(1), 52-56. 


\section{In the other editions}

Šlikas, Dominykas; Kalantaitè, Aušra; Krikštaponis, Boleslovas; Paršeliūnas, Eimuntas; Birvydiene, Rosita. On evaluation of the digital terrain model generated from the LiDAR data of Lithuanian territory. 9th International Conference "Environmental Engineering", May 22-23, 2014, Vilnius, Lithuania: selected papers. Vilnius : Technika, 2014. ISSN 2029-7092, 1-10.

Šlikas, Dominykas; Kalantaite, Aušra; Popovas, Darius; Paršeliūnas, Eimuntas Kazimieras. 2014. On optimization issue to generate the digital open space surface. 9th International Conference "Environmental Engineering", May 22-23, 2014, Vilnius, Lithuania. Vilnius : Technika, 2014. ISSN 2029-7092, 1-6.

Kalantaitè, Aušra; Šlikas, Dominykas. 2011. The analysis of data collected applying LIDAR method. 8th International Conference "Environmental Engineering", May 19-20, 2011, Vilnius, Lithuania : selected papers. Vol. 3. Sustainable Urban development. Roads and Railways. Technologies of Geodesy and Cadastre. Vilnius : Technika, 2011. ISSN 2029-7106, 1348-1351.

Papšienè, Lina; Kalantaite, Aušra; Papšys, Kęstutis. Conceptual model for generalisation of Lithuanian spatial reference data // 8th International Conference "Environmental Engineering", May 19-20, 2011, Vilnius, Lithuania : selected papers. Vol. 3. Sustainable Urban development. Roads and Railways. Technologies of Geodesy and Cadastre. Vilnius: Technika, 2011. ISSN 2029-7106, 1402-1407.

\section{About the author}

Aušra Kalantaitė received bachelor's qualification degree in Measurements Engineering at Vilnius Gediminas Technical University in 1994. Master of Science in Measurements Engineering at the same university in 1997. In 20092015 - doctoral student at Vilnius Gediminas Technical University. At present she works at the Ministry of Agriculture of Lithuania. 


\section{LIDAR MATAVIMUU IR TAIKYMU TECHNOLOGIJU TOBULINIMAS FIZINIAM ŽEMÉS PAVIRŠIUI MODELIUOTI}

Problemos formulavimas. Keletą paskutiniujų metų lazerinio skenavimo sistemos sparčiai tobulinamos, tampa vis tikslesnès ir patikimesnès. Tai tapo vienas iš greitų būdų gauti fizinio žemès paviršiaus modelius. Dẻl skenuojant gaunamo ypatingai didelio duomenų kiekio rankinis skenavimo rezultatų filtravimas ir kokybės kontrolè tampa neįmanoma. Automatiniai filtravimo metodai būtini ir yra aktyviai tyrinejami.

Disertacijoje yra sprendžiamos fizinio žemès paviršiaus modeliavimo problemos. Modeliuojant fizinį žemès paviršių reikia eliminuoti perteklinius automatizuotais lazerinio skenavimo metodais sukauptus aukščiu matavimus; pagal vietovès aukščių matavimus automatizuotai būtina išskirti žemès paviršiaus lūžio linijas; reikia îvertinti aukščių interpoliavimo tikslumą. Sprendžiant pirmą problemą būtina išsaugoti paviršiaus charakteringumą paliekant būdingus paviršiaus taškus, tačiau eliminuojant nesvarbius taškus. Sprendžiant antrą problemą, reikia surasti matavimų taškus, kurie yra staigaus paviršiaus kitimo vietose (šlaitų, skardžių ir pan. kraštuose). Sprendžiant trečią problemą, reikia atlikti ịvairiapusę matematinę-statistinę matavimų rezultatų analizę.

Charakteringiems taškams atrinkti tinka taikyti atstumų ir aukščio skirtumų tarp tiriamo ir kaimyninių taškų analizę. Šiais metodais galima vertinti ar tiriamasis taškas gali būti laikomas kaip neišsiskiriantis priimtos tolerancijos ribose. Charakteringiems taškams atrinkti reikia sukurti algoritmą, kuris vertintų kiekvieno taško kaimynystės analizès rezultatus. Disertacijoje siūlomas lazerinio skenavimo matavimų rezultatų filtravimo algoritmas paremtas lokalių plokštumų taikymais.

Darbo aktualumas. Geodezijos, kartografijos, geologijos, žemės administravimo, statybos ir kitoms reikmėms reikalinga informacija apie vietovès objektus. Šiai informacijai sukaupti vietoveje atliekami objektu padèties matavimai, sudaromi skaitmeniniai topografiniai planai, kita kartografinè medžiaga. Matuojant vietovės aukščius tradiciniais metodais, t.y. elektroniniais tacheometrais, paprastai surenkamas minimalus informacijos kiekis. Žemas aukščio taškų tankis reljefingoje vietovejje būna nepakankamas sukurti kokybišką fizinio žemės paviršiaus modelị. Todèl šiuo metu didelès apimties ir aukšto tikslumo skaitmeniniam vietovès paviršiaus modeliui sudaryti plačiai taikomas skenavimo iš orlaivių arba antžeminio skenavimo metodai.

Pirminiai LIDAR sistemos surinkti duomenys apima ne tik fizinio žemès paviršiaus aukščius, bet taip pat augalijos, statinių, pastatų ir kitų objektų paviršių aukščius (Digital Terrain Model, DTM). Lazeriniu skenavimu 
sukuriamas tankus trimatis taškų masyvas. Masyvas apima visus i skenerio matymo lauką patekusius objektus. Daugelyje taikymų, pvz. siekiant išbraižyti horizontales, kelių projektavime, tūrių skaičiavimams, krantų erozijai stebèti reikia fizinio žemès paviršiaus modelio (Digital Surface Model, DSM), kuriame būtų tiksliai identifikuotos reljefo lūžio linijos. Neapdoroti LIDAR duomenys yra mažai naudingi statybų projektavimo ir statybos procesuose.

Masyvo apimtis turi būti pakankama kokybiškam paviršiui sukurti ir tuo pačiu jis neturi turèti perteklinių taškų. LIDAR skenavimo žemės paviršiaus duomenys kai kuriems uždaviniams yra pertekliniai, t.y. taškai tankiai dengia tiek lygius paviršius, tiek paviršiaus briaunas. Kuriant žemės paviršiaus modelius pertekliniai taškai tampa paviršiaus tinklo mazginiais taškais ir taip sukuriami nebūtini paviršiui išreikšti tinklo elementai.

\section{Tyrimo objektas}

Fizinio žemės paviršiaus modeliavimas pagal pirminius LIDAR matavimų rezultatus.

Darbo tikslas

Patobulinti LIDAR matavimų rezultatų matematinio apdorojimo metodiką fiziniam žemès paviršiui modeliuoti.

\section{Darbo uždaviniai}

1. Atlikti LIDAR matavimu rezultatu matematinio apdorojimo metodikų mokslinès literatūros apžvalgą.

2. Ištirti komercineje programineje irangoje taikomo filtravimo algoritmo ịtaką fizinio žemès paviršiaus modelio kokybei.

3. Pasiūlyti perteklinių LIDAR matavimų rezultatų eliminavimo algoritmą.

4. İvertinti parengtų fizinio žemès paviršiaus modelių tikslumą.

\section{Tyrimu metodika}

Tyrimui LIDAR pertekliniams matavimams filtruoti buvo naudojama lokalių plokštumų pritaikymo metodika, o tyrimui žemės fiziniam paviršiui modeliuoti buvo naudojami interpoliacijos bei statistinès analizès metodai.

\section{Darbo mokslinis naujumas}

Remiantis disertacijoje atliktais tyrimais gauti šie matavimų inžinerijos mokslui nauji rezultatai:

1. Pasiūlytas algoritmas pertekliniams LIDAR matavimu rezultatams eliminuoti, sumažinantis LIDAR duomenų masyvo apimtị, bet nekeičiantis žemės paviršiaus modelių kokybès. 
2. Nustatytos geodezinių aukščių taškų eliminavimo algoritmų parametru ribos, kuriose žemès paviršiaus modelio kokybè išlieka nepakitusi.

3. Taikant matematinès statistikos metodus ịvertinta žemès paviršiaus modelių tikslumas kai interpoliuojama lokaliais metodais.

4. Taikant matematinès statistikos metodus ịvertinta keleto skirtingu LIDAR matavimo rezultatų tikslumas.

\section{Praktinè reikšmé}

Sudarytas LIDAR matavimų rezultatu apdorojimo algoritmas orientuotas i nekomercinių funkcijų bibliotekas. Sudaryta programine ịranga filtruoti LIDAR duomenys ir gauti fizinio žemės paviršiaus modeliai tinka projektavimo, statybų procesams ir kitoms reikmėms. Pagal LIDAR matavimų rezultatus parengtas šiuo metu aukščiausio tikslumo Lietuvos teritorijos reljefo modelis.

\section{Ginamieji teiginiai}

1. Taikant pasiūlytą perteklinių LIDAR matavimų rezultatų eliminavimo algoritmą galima sumažinti taškų masyvą, nekeičiant žemès paviršiaus modelio kokybès.

2. Taikant žemės paviršiaus briaunų suradimo algoritmą galima nustatyti žemės paviršiaus briaunas planiniu tikslumu tinkamu sudaryti M 1:2000 ir smulkesnio mastelio žemèlapius.

3. Metodikoje, pagal kurią nustatomos žemès paviršiaus modelių rodiklių reikšmès, būtina ịvertinti rodiklių tikslumo parametrus.

\section{Darbo rezultatu aprobavimas}

Disertacijos tema išspausdinta 11 publikacijų: 1 straipsnis publikuotas ISI Web of Science žurnale, 6 straipsniai recenzuojamuose mokslo žurnaluose, 4 ISI Proceedings duomenų bazejje.

Disertacijoje atliktų tyrimų rezultatai buvo paskelbti 2 tarptautinèse mokslinėse konferencijose Vilniuje: „Environmental Engineering“ 2011 ir $2014 \mathrm{~m}$.

\section{Mokslinio darbo apimtis}

Disertaciją sudaro įvadas, 3 skyriai ir bendros išvados.

Darbo apimtis yra 108 puslapiai, pateikta 43 numeruotos formulès, 62 paveikslai ir 17 lentelių. Rašant disertaciją naudotasi 113 literatūros šaltiniais. Pirmame skyriuje aprašoma kitų autorių tyrimai. Antrame skyriuje aprašomas perteklinio LIDAR taškų masyvo filtravimas, eliminuojant perteklinius taškus. Trečiame skyriuje nagrinejjami vektorinių ir rastrinių fizinio žemès paviršiaus modeliu sudarymo skirtumai. 


\section{Bendrosios išvados}

1. Patobulinta LIDAR matavimų rezultatų matematinio apdorojimo metodika pasiūlant perteklinių matavimų rezultatų eliminavimo algoritmą pritaikantị plokštumas. Taikant siūlomą algoritmą LIDAR matavimų rezultatų masyvas gali būti sumažinamas keletą kartų nepakeičiant sudaromo fizinio žemès paviršiaus modelio kokybès.

2. Eksperimentais pagrịsta, kad pradinị LIDAR matavimų rezultatų rinkinị suskirsčius ị GRID ląsteles, pakartotina interpoliacija šių ląstelių reikšmių pagrindu nepadidina ieškomų taškų aukščių tikslumo. Tokiu būdu daroma išvada, kad tikslesnèms nežinomų taškų reikšmėms gauti reikia interpoliuoti pradinị LIDAR matavimų taškų rinkinį.

3. Tyrimo rezultatais pagrista, kad interpoliuotu LIDAR duomenu tikslumas atvirose vietovėse lyginant su pradiniais LIDAR matavimais sumažeja, t.y. aukščio klaidų atviroje vietovejje ekstremumai padideja beveik 2 kartus. Vietovès dangos rūšies atspindžio įtakotas aukščio tikslumas turi mažesnę įtaka už vietovejje esančius paviršiaus lūžius, kurie interpoliuojant sumažina modelio aukščiu tikslumą. Tyrimo rezultatais pagrista, kad miškingose teritorijose lazerinio skenavimo duomenų aukščiu tikslumo nepakanka planuojant tinklų inžinerinę infrastruktūrą (standartinis nuokrypis yra 1,10 m). LIDAR duomenys miškuose gali būti taikomi priešprojektiniams tyrimams (pvz. geležinkelių, kelių trasų parinkimui).

4. Eksperimentiniais tyrimais pagrịsta, kad pagal urbanizuotu teritorijų LIDAR matavimų rezultatus (skrydžio aukštis ne didesnis už $800 \mathrm{~m}$, LIDAR taškų tankis ne mažesnis už 4 taškus kv. metre) sudaryto žemès paviršiaus modelio tikslumas tenkina 1:500 - 1:2000 mastelio urbanizuotų teritorijų plètros planų reikalavimus topografiniam pagrindui: gauti aukščiu vidutiniai nuokrypiai neviršija $0,10 \mathrm{~m}$, o planinès padèties nuokrypiai $0,25 \mathrm{~m}$. Šio modelio tikslumas netenkina statybos projektams keliamų reikalavimų, nes aukščio paklaidos viršija $0,08 \mathrm{~m}$. 